\title{
Knowledge-Intensive Business Services in Russia: 2014-2015 Crisis Aftermath
}

\author{
Veronika Belousova ${ }^{a}$ \\ Associate Professor and Head, vbelousova@hse.ru \\ Nikolay Chichkanov ${ }^{\text {a }}$ \\ Research Assistant, nik.chichkanov@gmail.com
}

a Department for Methodology of Budget Planning, Institute for Statistical Studies and Economics of Knowledge,
National Research University Higher School of Economics, 11 Myasnitskaya str., 101000 Moscow, Russian Federation

\begin{abstract}
$\mathrm{I}$ $\mathrm{n}$ recent years, knowledge-intensive business services (KIBS) have become extremely important in the knowledge-based economy. KIBS concentrate a well-qualified workforce and create high levels of valueadded services, serve as a driver for the innovationbased development of many countries [Santos-Vijande et al., 2013]. However, the growth rates of this sector in Russia considerably fell after the 2008 crisis; some KIBS-industries could not even reach pre-crisis volumes of production and the share of this sector in GDP significantly declined [Berezin, Doroshenko, 2015]. The crisis trends in Russian economy at the end of 2014 and

at the beginning of 2015 had a strong negative impact on KIBS.

We show that the share of companies with decreasing revenues has dramatically grown in all industries. The demand side has also changed: the client base is now more unstable and customers more regularly fail to fulfill contract obligations. An industry analysis reveals significant divergences in the rates and trajectories for development of Russian KIBS industries. However, the sector heterogeneity might be also found in KIBS of other countries. The paper is based on both survey of 656 Russian KIBS producers and in-depth interviews with 24 leading KIBS experts.
\end{abstract}

Keywords: service economy; knowledge-intensive business services; crisis; industrial analysis; knowledge-intensive business services producers; knowledge-intensive business services consumers.

DOI: $10.17323 / 1995-459 X .2016 .4 .46 .58$

Citation: Belousova V., Chichkanov N. (2016) KnowledgeIntensive Business Services in Russia: 2014-2015 Crisis Aftermath. Foresight and STI Governance, vol. 10 , no 4, pp. 46-58. DOI: 10.17323/1995459X.2016.4.46.58. 
$\mathrm{T}$ he service sector plays a key role in most of today's developed economies. The World Bank estimated its contribution to GDP and employment in various developed countries (such as Canada, the US, Japan, and Australia) in excess of 70\% in 2012-2013 [Quandl, 2016a]. A similar situation was observed in Russia, among various other aftereffects of the catch-up development paradigm: the service sector's contribution to the nation's GDP in 2013 amounted to $59.78 \%$, and its share of the total employment in 2009 was 62.3\% [Quandl, 2016a, 2016b]. One of the most important segments of the service sector is knowledge-intensive business services (KIBS); it has the highest innovation potential and acts as a driver of the whole sector's growth [Santos-Vijande et al., 2013]. Since the KIBS market players mostly work with international companies [Zieba, 2013], their operations affect the whole economy [Asikainen, 2015]. Finally, the sector traditionally employs a large share of highly skilled personnel and generates steadily growing added value created by 'smart' labour producing knowledge-intensive services [Muller, Zenker, 2001].

Scholars usually adopt an integrated approach when assessing the KIBS sector's role in innovation. On the one hand, the sector's companies act as a kind of brokers who help to find and process information, and bring together other participants of the innovation process [Muller, Doloreux, 2009; Consoli, ElcheHortelano, 2010]. Their activities directly affect the rate of innovations' dissemination, since they deal with large and small companies in various regions [Doloreux, Shearmur, 2013]. Researchers note that competition forces players in different market segments to increase their specialisation and protect their niches [Aslesen, Isaksen, 2010]. The knowledge-intensive services sector offers increased opportunities for outsourcing advertising, audit, and other services, thus helping companies strengthen their competitive advantages by concentrating on producing unique products. At the same time, in recent years the sector's companies increasingly often acted not just as brokers but also as actual innovators [Muller, Doloreux, 2009; Doloreux et al., 2010], making use of their access to their clients' data, accumulated knowledge and experience. The latter allows one to adapt products and services to specific clients' needs to the maximum extent possible, abandoning uniform approaches [Doloreux, Shearmur, 2010].

A specific feature of the KIBS sector is the actual 'production process' which typically involves very close interaction with clients, thus allowing one to speak of 'coproduction'. Coproduction and client relations issues as "inherent components of innovation and production processes" [Asikainen, 2015, p. 81] remain at the core of numerous international [Corrocher et al., 2009; Bettiol et al., 2011] and Russian [Doroshenko et al., 2013; Doroshenko et al., 2014] studies. The authors of a review of Russian KIBS companies' operations in 2005-2013 [Berezin, Doroshenko, 2015] noted that in 2010-2012, the post-recession recovery in most industries of the sector was slow, while its contribution to GDP fell to 2.5-2.8\% (compared with 3.8-4.1\% before the crisis). Such services as engineering, design, and development have never managed to return to the level of 2008 . The 2008 crisis had a very negative overall effect on the sector: in various industries the output fell by between $25 \%$ and $60 \%$.

The most recent expert assessments of the KIBS sector's output and growth rates in 2005-2015, for the whole sector and its ten segments, can be found in [Berezin, 2016]. According to the author, growth rates in various segments of the sector started to differ in 2014. Three groups of markets were identified through an expert survey, based on their rouble-denominated nominal revenues' growth rates. The first group (design services) displayed a relatively high growth rate of this indicator; in the second group (advertising, marketing, ICT, and engineering services) costs were growing at a higher rate than revenues; and in the third group (audit, consulting, and leasing services) revenues started to decline as early as the second half of 2014. The data presented in the study allows one to divide the above segments into growing, moderately declining, and rapidly declining ones. According to the experts, differentiation of these markets has increased during the first half of 2015, with the 'depth of decline' becoming the main criterion for their classification. The reduction of rouble-denominated revenues in marketing, audit, consulting, engineering, and ICT services was rather small (5-7\%) while in design, financial, and HR services it was quite significant (up to $30 \%$ ).

The objective of our study is to analyse the trends in the knowledge-intensive services sector between the end of 2014 and the first half of 2015 - a period marked by adverse developments in the Russian economy. According to the Federal Statistics Service (Rosstat), in the first and second quarters of 2015 GDP fell by $2.79 \%$ and $4.52 \%$ compared with the relevant periods of 2014, respectively [Rosstat, 2016a]. Inflation increased significantly, reaching $4.8 \%$ in the fourth quarter of 2014 and $7.4 \%$ in the first quarter of 2015 [Rosstat, 2016b]; the average monthly rouble-to-dollar exchange rate steadily dropped between November and January, by 13\%, 21\%, and 17\%, respectively [CBR, 2016a]. The amount of bank loans issued to companies to upgrade their production capacity has noticeably decreased between 1 January, 2014 and 1 January, 2015, both in absolute (from 1,004 trillion to 918.0 billion roubles) and relative terms (from $10 \%$ to $9.3 \%$ of companies' total capital investments) [CBR, 2016b].

Empirically, the study is based upon the data collected over the course of the ongoing Monitoring of Knowledge-Intensive Business Services in Russia (Monitoring), a study conducted by the HSE Institute of Statistical Studies and Economics of Knowledge (ISSEK) since 2006 jointly with Romir Research Holding in the scope of the HSE Basic Research Programme ${ }^{1} .656$ Russian companies - producers of

See https://www.hse.ru/monitoring/intel for more (last accessed on 02.05.2016). 
Figure 1. Turnover (revenue) growth of the knowledge-intensive services sector companies in 2014 - the first half of $2015(\%), \mathrm{n}=656$

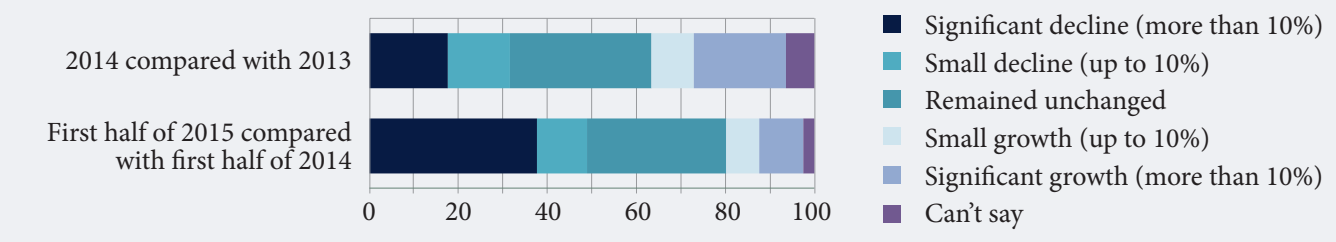

Note: This and subsequent figures and tables are compiled by the authors using data from the HSE ISSEK study

"Monitoring of Knowledge-Intensive Business Services in Russia".

knowledge-intensive services were surveyed in 2015, the respondents included managers and leading staff members. The sample was designed on the basis of a pilot survey of 50 respondents conducted to test the specially developed toolset. It strictly matched the survey's objectives and methodology and was representative (it covered all segments of the sector). The industry's geographical diversity was also taken into account: the sample proportionally reflects each Russian region's share of the gross regional product (GRP) in the combined GRP of the 14 most economically developed regions of the country.

The sector's quantitative characteristics were supplemented with a qualitative analysis: 24 in-depth interviews were conducted with leading experts in the relevant fields holding senior positions at industrial associations and major self-regulating organisations. Each of the experts had a very good understanding of the current state of and prospects for the relevant segments, while the total number of the respondents was determined taking into account the results of similar international studies ${ }^{2}$. For example, according to Kathy Charmaz's calculations, for small projects 25 respondents are enough to make a qualitative study reliable [Charmaz, 2006, p. 114]. Judith Green and Nicki Thorogood agree with her; they note that after 20 interviews respondents' input becomes noticeably less original [Green, Thorogood, 2004, p. 103-104]. Abbie Griffin and John Hauser revealed that $90 \%$ of all clients' needs can be met by conducting 20-30 indepth interviews [Griffin, Hauser, 1993, p. 23]; having analysed 100 studies, Stanley Bruce Thomson sets the ceiling for the number of respondents at about the same level (30 interviews) [Thomson, 2011, p. 50].

Our study is structured in the following way: the first section presents indicators for measuring KIBS producers' performance. The second section analyses changes in their customers' behaviour, i.e. factors affecting demand. Results of the sector's analysis and main conclusions are presented in the final section.

\section{Producers of knowledge-intensive business services in 2014-2015}

The overall negative situation in the Russian economy cannot avoid affecting the KIBS sector as well. If after 2014 about a third of the companies participating in the survey reported an increase of their annual rouble-denominated revenues, after the first six months of 2015 their share had almost halved. At the same time, the share of companies who have managed to maintain their turnover level remained practically unchanged. Thus, the reduced number of companies whose business has grown was due to the significantly larger number of firms whose revenues have shrunk. The share of market players whose rouble-denominated turnover has dropped significantly (by more than 10\%) grew from $18 \%$ to $38 \%$. Changes in companies' turnover growth rates are shown in Figure 1.

The KIBS sector's costs structure is quite unusual: personnel costs account for about $50 \%$ of them in all aforementioned segments. The lowest level of this indicator is noted in IT consulting services (45.2\%), the highest - in audit and management consulting (53.18\%). The median value for 8 out of 10 industries is $50 \%$, and for the remaining two $-45 \%$. The data collected through a quantitative survey conducted in the framework of the Monitoring study is presented in Table 1.

According to the surveys, at just over a half of the sector's companies, the number of staff and the average rouble-denominated wage remained unchanged between the autumn of 2014 and late summer of 2015. The reduction of the number of employees and the average rouble wage was reported by almost $30 \%$ and $23 \%$ of the companies, respectively (see Table 2 ).

The experts, the participants in the in-depth interviews, have also confirmed the overall negative trends in the sector. Most of them noted that though big players in the knowledge-intensive services market on the whole have retained their positions, some of them did experience certain contraction. In this context, this means various forms of cost optimisation such as wage cuts, layoffs, moving to smaller premises, etc. The shares of small and medium companies who had to leave the market are much larger. According to

\footnotetext{
Other opinions about what sample size can be considered sufficient also exist; the most comprehensive review of relevant sociological studies can be found in [Rozhdestvenskaya, 2012, pp. 70-73].
} 
Table 1. The share of the knowledge-intensive services sector companies' personnel costs, including wages/salaries, bonuses, benefits, taxes, and deductions, $n=656$

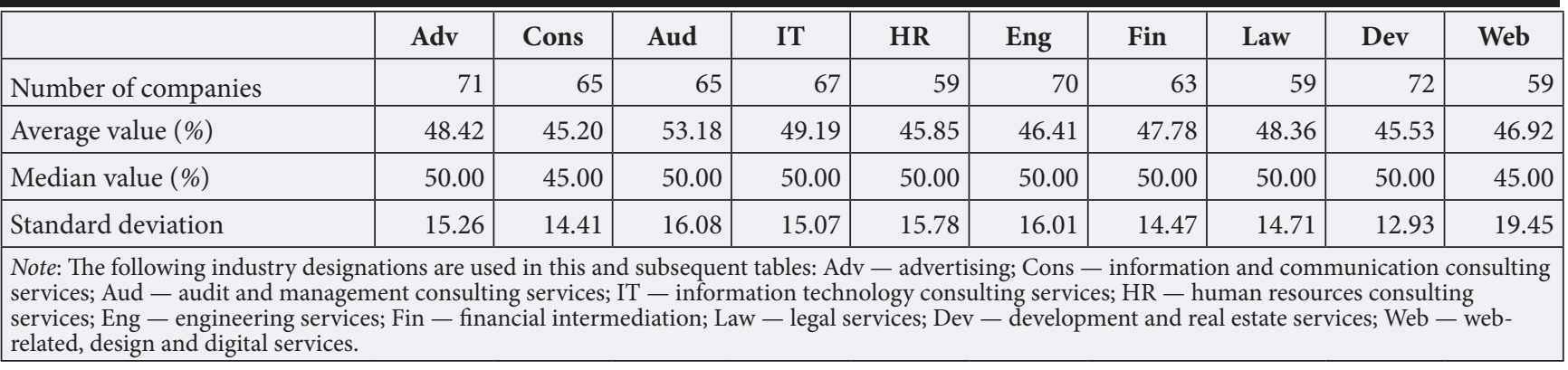

the respondents, in many cases this was due to such companies' origins: they were created at the peak of economic growth, they could not cope with a recession and had to discontinue operations. However, in most cases this was a temporary measure, until the economy's next upward swing. Some of the small companies were absorbed by larger ones, employees of others became freelancers or 'came home' - i.e., got hired by their old employers' clients. This is particularly common in legal services, HR consulting, and management.

No noteworthy new players appeared in any of the sector's segments - which some of the experts believed was perfectly natural in a stagnating economy. Stagnation is not total, however: medium and small companies not only leave the market but also enter it. Another trend noted by the experts was professionals' "circulating" within a stable pool: when a company closes down some of its employees begin to engage in freelance work, or companies may split into several smaller ones. These factors ensure a steady labour supply for segments like HR and legal services. However, these processes do not always involve the emergence of new service providers.

\section{Demand trends}

The main users of knowledge-intensive services are other companies, so the sector's players are somewhat dependent on their clients' financial situation. During the first six months of 2015, only half of the companies received full payment for services provided on time, in line with previously signed contracts. Customers of another $24 \%$ of companies did not pay on time up to $10 \%$ of the contract value. $16 \%$ more of the respondents reported aggregate unpaid debt of between $11 \%$ and $20 \%$ of the total contract value (Figure 2).

The experts identified several trends in the structure of KIBS companies' clients (Table 3). Firstly, the recession could not but affect demand - the number of new customers is shrinking. However, in most industries a degree of substitution does take place: new entrants come to replace the players who have left the market, mostly from the ranks of former clients - 'new customers in old industries'. Car makers are most frequently mentioned among those leaving the market, while the majority of new entrants is made up of agricultural and pharmaceutical companies.

Another noticeable trend is major budget cuts, and therefore reduced procurement by many existing customers. On the other hand, the client base in certain industries of the sector - such as IT, legal, HR services, etc. did not experience any significant changes. However, the experts also noted that clients became more demanding about the services they order, while the average order value and the rate of inquiries' conversion into actual orders keep dropping.

Thirdly, the importance of the public sector as a steady buyer of IT services is growing. Government agencies and state-owned companies are becoming new clients on the advertising, engineering, and

Table 2. Breakdown of the knowledge-intensive services sector companies by change of the number of employees and the average rouble wage between early autumn of 2014 and late summer of $2015(\%), \mathbf{n}=656$

\begin{tabular}{|l|r|l|r|}
\hline \multicolumn{2}{|c|}{ Change of the number of employees } & \multicolumn{2}{c|}{ Change of the average rouble wage } \\
\hline Small reduction (under 5\%) & 8.84 & Small reduction (under 5\%) & 5.18 \\
\hline Reduction (5-20\%) & 14.63 & Reduction (5-20\%) & 13.57 \\
\hline Significant reduction (over 20\%) & 6.25 & Significant reduction (over 20\%) & 4.57 \\
\hline Remained unchanged & 52.44 & Remained unchanged & 56.10 \\
\hline Small increase (under 5\%) & 2.75 & Small increase (under 5\%) & 4.12 \\
\hline Increase (5-20\%) & 4.88 & Increase (5-20\%) & 7.77 \\
\hline Significant increase (over 20\%) & 2.44 & Significant increase (over 20\%) & 1.37 \\
\hline Can't say & 7.77 & Can't say & 7.32 \\
\hline
\end{tabular}




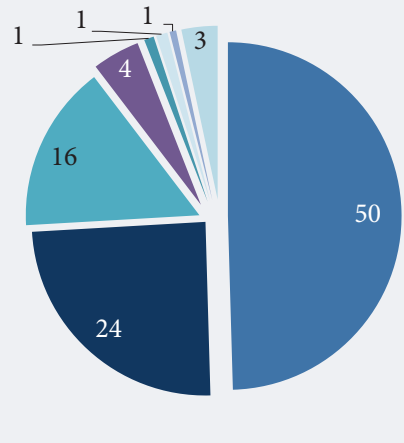

- All contracts completed during the period paid in full

- Less than $10 \%$ of contract value not paid on time

- $11-20 \%$ of contract value not paid on time

- $21-30 \%$ of contract value not paid on time

- $31-40 \%$ of contract value not paid on time

$41-50 \%$ of contract value not paid on time

- More than $50 \%$ of contract value not paid on time

Can't say

design services markets. In the latter case, increased demand was noted not just by government agencies as such (including the Ministry of Defence, Ministry of Culture, etc.), but by their staff members acting as individuals.

The experts' conclusions on the whole match the above data. Indeed only a third of the companies managed to keep their client base during the last 18 months, while a quarter of the players have lost $5-10 \%$ of their former clients, and almost $16 \%$ more companies lost $11-20 \%$ of their customers. At the same time, only one company in five were unable to attract any new clients; most of the firms (about $61.6 \%$ ) did find new customers, with the latter's share in the companies' client base growing by 5-10\% or by $11-20 \%$. Client base dynamics are shown in Figure 3.

A parallel analysis of both these client base trends provides the best picture of what is actually happening in the sector: the recession led to the client base shrinking at $27 \%$ of the companies, while the same share of market players managed to retain the number of their customers at a level close to the pre-recession one.

Approximately $38 \%$ of the companies reported an increase of their client base. The experts attribute this to the fluctuations of the rouble exchange rate hindering access to services offered by foreign companies, thus prompting customers to switch to Russian suppliers. Another recession-induced factor may also have played a role: after some service providers left the market the remaining players divided their former customers between themselves (while the total number of customers remained unchanged).

\section{Sector-specific features}

The knowledge-intensive services sector is highly diverse, in Europe [Camacho, Rodriguez, 2008] and Russia [Doroshenko et al., 2014] alike. The sector's industries are quite different, not just in terms of the underlying knowledge base but also in the nature of services provided [Freel, 2010]. Two groups of industries are traditionally identified - professional knowledge-intensive business services (P-KIBS) such as accounting or legal services, and new technological knowledge-intensive business services (T-KIBS) [Miles, 1993], e.g. IT-related services [Muller, Doloreux, 2009; Consoli, Elche-Hortelano, 2010]. T-KIBS largely depend on R\&D, while organisational and management approaches and practices play

\section{Table 3. Breakdown of the knowledge-intensive services sector companies by change in the customer structure between early autumn of 2014 and late summer of $2015(\%), n=656$}

\begin{tabular}{|c|c|c|c|}
\hline \multicolumn{2}{|c|}{$\begin{array}{l}\text { Question to respondents: } \\
\text { Please estimate the share of clients }(\%) \text { who have } \\
\text { left the market in the last } 18 \text { months out of the } \\
\text { total number in the first quarter of } 2014\end{array}$} & \multicolumn{2}{|c|}{$\begin{array}{l}\text { Question to respondents: } \\
\text { Please estimate the share of new clients }(\%) \text { who have } \\
\text { entered the market in the last } 18 \text { months out of the total } \\
\text { number of customers in the third quarter of } 2015\end{array}$} \\
\hline All customers are still there & 34.45 & No new customers & 19.67 \\
\hline $5-10 \%$ & 24.8 & $5-10 \%$ & 40.09 \\
\hline $11-20 \%$ & 15.70 & $11-20 \%$ & 21.49 \\
\hline $21-30 \%$ & 6.86 & $21-30 \%$ & 6.56 \\
\hline $31-40 \%$ & 5.03 & $31-40 \%$ & 2.13 \\
\hline $41-50 \%$ & 2.13 & $41-50 \%$ & 1.37 \\
\hline More than $50 \%$ & 4.73 & More than $50 \%$ & 7.32 \\
\hline Can't say & 6.25 & Can't say & 1.37 \\
\hline
\end{tabular}




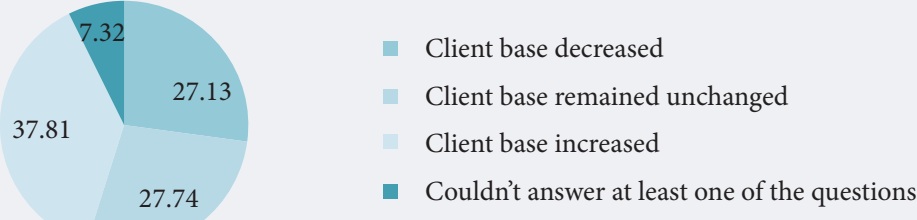

a key role in providing P-KIBS [Freel, 2010]. Recently creative segments of the knowledge-intensive services sector (advertising, design, multimedia, branding, etc.) were included in a category of their own [Marasco et al., 2013].

The above segmentation of the sector was also confirmed by in-depth interviews with Russian experts, many of whom pointed out various industries' specific features. This article will take a look at the expert assessments of changes in the knowledge-intensive services sector broken down by industries. The dynamics of all the aforementioned indicators (revenues, order and customer structures, personnel, wages) are presented in Tables 4-9, by industry. This data is supplemented by analysis of in-depth interviews with experts in specific industries, including PR, knowledge management, design, and development services.

\section{Advertising services}

According to the experts, in 2014 the advertising market grew in rouble terms but contracted in US dollar terms, because it directly depends on the overall economic situation. This market's volume allows one to tie customers' advertising expenditures to fluctuations in GDP. One of the experts noted that "when GDP grows, advertising expenditures also grow. If GDP shrinks, advertising expenditures also shrink". In 2015, the market's growth rate was expected to slow down by approximately $10 \%$, with a possible increase of certain players' market shares. These forecasts came true: in the first six months of 2015 the share of advertising companies whose revenues fell by more than $10 \%$ was higher than in any other segment of the KIBS sector (see Table 4). At the same time, the share of companies whose revenues grew by more than $10 \%$ was also the highest in this segment. Similarly, the number of employees (Table 5) and labour cost (Table 6) indicators have also shown contradictory dynamics. Possibly that was the reason the experts did not describe the situation on the advertising market as a crisis.

Our study shows that most of the new players in this industry are 'pocket' advertising agencies, or were set up following companies' splitting up, or registered as affiliates of existing firms. Whether such processes can be interpreted as the emergence of new market players remains an open question.

As to clients, on the one hand, companies have been cutting their advertising costs due to fluctuations of the rouble's exchange rate, while on the other, local advertisers have stepped up their activities to

Table 4. Breakdown of the knowledge-intensive services sector companies by revenue growth, by industry (\%), $\mathrm{n}=656$

\begin{tabular}{|c|c|c|c|c|c|c|c|c|c|c|c|}
\hline \multicolumn{12}{|c|}{2014 compared with 2013 (\%) } \\
\hline & Adv & Cons & Aud & IT & HR & Eng & Fin & Law & Dev & Web & All \\
\hline Significant decrease (more than 10\%) & 20.8 & 15.4 & 19.7 & 17.9 & 10.2 & 32.4 & 10.9 & 25.4 & 16.2 & 5.1 & 17.6 \\
\hline Small decrease (less than 10\%) & 9.7 & 16.9 & 9.1 & 13.4 & 16.9 & 8.5 & 15.7 & 25.4 & 14.9 & 11.9 & 14.0 \\
\hline Remained unchanged & 26.4 & 32.3 & 36.4 & 26.9 & 39.0 & 36.6 & 37.5 & 20.3 & 23.0 & 42.3 & 31.7 \\
\hline Small increase (less than $10 \%)$ & 13.9 & 9.2 & 9.1 & 11.9 & 6.8 & 5.6 & 15.6 & 5.1 & 12.2 & 5.1 & 9.6 \\
\hline Significant increase (more than $10 \%$ ) & 25.0 & 21.6 & 19.7 & 23.9 & 18.6 & 8.5 & 15.6 & 17.0 & 24.3 & 33.9 & 20.7 \\
\hline Can't say & 4.2 & 4.6 & 6.0 & 6.0 & 8.5 & 8.4 & 4.7 & 6.8 & 9.4 & 1.7 & 6.4 \\
\hline \multicolumn{12}{|c|}{ First six months of 2015 compared with first six months of 2014 (\%) } \\
\hline & Adv & Cons & Aud & IT & HR & Eng & Fin & Law & Dev & Web & All \\
\hline Significant decrease (more than 10\%) & 48.6 & 40.0 & 37.9 & 31.3 & 33.9 & 46.5 & 21.9 & 44.1 & 48.6 & 18.6 & 37.7 \\
\hline Small decrease (less than 10\%) & 8.4 & 15.4 & 12.1 & 11.9 & 8.4 & 8.4 & 14.1 & 13.6 & 9.5 & 11.9 & 11.3 \\
\hline Remained unchanged & 22.2 & 33.8 & 39.4 & 37.3 & 44.1 & 28.2 & 42.2 & 20.3 & 17.6 & 30.5 & 31.2 \\
\hline Small increase (less than 10\%) & 11.1 & 6.2 & 1.5 & 6.0 & 6.8 & 5.6 & 10.9 & 3.4 & 13.5 & 8.5 & 7.5 \\
\hline Significant increase (more than 10\%) & 9.7 & 3.1 & 7.6 & 9.0 & 6.8 & 8.5 & 9.4 & 15.2 & 6.7 & 25.4 & 9.9 \\
\hline Can't say & 0.0 & 1.5 & 1.5 & 4.5 & 0.0 & 2.8 & 1.5 & 3.4 & 4.1 & 5.1 & 2.4 \\
\hline
\end{tabular}


Table 5. Breakdown of the knowledge-intensive services sector companies by change in the number of employees between early autumn of 2014 and late summer of 2015, by industry (\%), $\mathbf{n}=656$

\begin{tabular}{|l|r|r|r|r|r|r|r|r|r|r|r|}
\hline & Adv & Cons & Aud & IT & HR & Eng & Fin & Law & Dev & Web & All \\
\hline Significant decrease (more than 20\%) & 9.7 & 3.1 & 7.6 & 7.4 & 6.8 & 12.7 & 6.2 & 3.4 & 2.7 & 1.7 & 6.3 \\
\hline Decrease (5-20\%) & 19.5 & 16.9 & 15.2 & 7.5 & 8.4 & 12.7 & 12.5 & 30.5 & 18.9 & 3.4 & 14.6 \\
\hline Small decrease (less than 5\%) & 11.1 & 10.8 & 9.1 & 3.0 & 6.8 & 4.2 & 15.6 & 8.5 & 12.2 & 6.8 & 8.9 \\
\hline Remained unchanged & 40.3 & 50.8 & 51.5 & 55.2 & 62.7 & 54.9 & 56.3 & 49.1 & 45.9 & 61.0 & 52.4 \\
\hline Small increase (less than 5\%) & 1.4 & 7.7 & 1.5 & 3.0 & 3.4 & 2.8 & 1.6 & 1.7 & 1.4 & 3.4 & 2.7 \\
\hline Increase (5-20\%) & 8.3 & 4.6 & 0.0 & 9.0 & 5.1 & 1.4 & 3.1 & 3.4 & 8.1 & 5.1 & 4.9 \\
\hline Significant increase (more than 20\%) & 2.8 & 1.5 & 3.0 & 1.5 & 1.7 & 0.0 & 0.0 & 3.4 & 2.7 & 8.5 & 2.4 \\
\hline Can't say & 6.9 & 4.6 & 12.1 & 13.4 & 5.1 & 11.3 & 4.7 & 0.0 & 8.1 & 10.1 & 7.8 \\
\hline
\end{tabular}

promote sales in their home region and neighbouring ones. Still, if on the whole advertising companies' client base was replenished in line with the overall situation in the sector (Table 7), in terms of retaining former customers the industry significantly lagged behind others. Therefore, the share of advertising firms who have managed to keep all their clients is more than $33 \%$ smaller than the average for the KIBS sector (Table 8 ).

Large advertising agencies increasingly often take small companies' orders. If clients with a budget below a certain level used to be cut-off by default, this hardly ever happens now. The experts stressed that there was no evidence of customers returning to the advertising market.

\section{Marketing services}

Accurately estimating the volume of the marketing services market is not an easy task because customers spend a significant proportion of their budgets not on the market, but in-house by recruiting personnel or through subcontracting. There was also the double count problem - when the same contract was included in the parent company's, its regional partners', and subcontractors' accounting report, i.e., the nominal budget turns out much larger than the actual one. In certain areas, e.g., direct marketing, customers' budgets indeed were cut, while in others they remained unchanged. In turnover terms, the speed of sales is particularly important during a recession, so funds were allocated from the budgets to increase it by using various marketing techniques usually the budgets are not revised. Another feature of this industry is emergence of a separate 'digital marketing' segment.

When assessing the volume of the marketing services market, the experts noted the 'Olympic Games effect' referring to the significant amounts of money allocated in 2014 to fund the projects related with the Sochi Winter Olympics. Compared with that year, the contraction of the market in 2015 was significant while compared with 2013 it was more modest, at about 10\%. The surveyed experts attributed this to recession-induced uncertainty and even panic among clients. Providers of marketing services very much depend on their customers; when the latter have financial problems, they tend to cut marketing budgets before anything else, so the overall economic situation directly affects this industry.

\section{PR services}

Similar to the previous case, problems with assessing this market's volume are associated with the need to separate market trends from companies' internal activities. For companies, maintaining their own PR departments, creating content and organising events on their own absorb about $70-75 \%$ of the relevant budgets. Still, according to the experts, in rouble terms the market grew by $15-20 \%$ in 2013 ; no growth was noted in 2014, but no decline either. Forecasts for 2015 envisaged either zero growth or a decline of

\section{Table 6. Breakdown of the knowledge-intensive services sector companies by growth of the average rouble-denominated wage between early autumn of 2014 and late summer of 2015, by industry (\%), $n=656$}

\begin{tabular}{|l|r|r|r|r|r|r|r|r|r|r|r|}
\hline & Adv & Cons & Aud & IT & HR & Eng & Fin & Law & Dev & Web & All \\
\hline Significant decrease (more than 20\%) & 6.9 & 4.6 & 6.1 & 4.5 & 3.4 & 8.5 & 1.6 & 3.4 & 5.4 & 0.0 & 4.5 \\
\hline Decrease (5-20\%) & 22.2 & 13.9 & 13.6 & 4.5 & 13.5 & 15.5 & 15.6 & 11.8 & 20.3 & 1.7 & 13.6 \\
\hline Small decrease (less than 5\%) & 5.5 & 9.2 & 4.6 & 3.0 & 0.0 & 5.6 & 4.7 & 8.5 & 6.8 & 3.4 & 5.2 \\
\hline Remained unchanged & 38.9 & 55.4 & 54.5 & 64.2 & 69.5 & 52.1 & 65.6 & 66.1 & 40.5 & 61.0 & 56.1 \\
\hline Small increase (less than 5\%) & 5.6 & 1.5 & 1.5 & 3.0 & 6.8 & 2.8 & 6.2 & 3.4 & 5.4 & 5.1 & 4.1 \\
\hline Increase (5-20\%) & 12.5 & 7.7 & 9.1 & 11.9 & 3.4 & 4.2 & 1.6 & 3.4 & 8.1 & 15.2 & 7.8 \\
\hline Significant increase (more than 20\%) & 4.2 & 0.0 & 0.0 & 0.0 & 0.0 & 0.0 & 1.6 & 3.4 & 1.3 & 3.4 & 1.4 \\
\hline Can't say & 4.2 & 7.7 & 10.6 & 8.9 & 3.4 & 11.3 & 3.1 & 0.0 & 12.2 & 10.2 & 7.3 \\
\hline
\end{tabular}




\section{Table 7. Breakdown of the knowledge-intensive services sector companies by share of new customers} brought in between early autumn of 2014 and late summer of 2015, by industry (\%), $\mathbf{n}=\mathbf{6 5 6}$

\begin{tabular}{|c|c|c|c|c|c|c|c|c|c|c|c|}
\hline \multicolumn{12}{|c|}{$\begin{array}{l}\text { Question to respondents: Please estimate the share of new customers (\%) brought in during the last } 18 \text { months } \\
\text { in comparison with the total number of your company's clients in the third quarter of } 2015\end{array}$} \\
\hline & Adv & Cons & Aud & IT & HR & Eng & Fin & Law & Dev & Web & All \\
\hline No new customers & 19.4 & 16.9 & 25.8 & 17.9 & 25.4 & 36.6 & 17.2 & 13.6 & 9.5 & 13.5 & 19.7 \\
\hline $5-10 \%$ & 34.7 & 46.2 & 39.4 & 35.8 & 44.1 & 38.1 & 43.7 & 45.8 & 39.2 & 35.6 & 40.1 \\
\hline $11 \%-20 \%$ & 26.4 & 27.7 & 24.2 & 28.3 & 11.8 & 12.7 & 17.2 & 22.0 & 20.3 & 23.7 & 21.5 \\
\hline $21-30 \%$ & 4.2 & 1.6 & 6.1 & 7.5 & 11.9 & 2.8 & 12.5 & 3.4 & 8.1 & 8.5 & 6.5 \\
\hline $31-40 \%$ & 2.8 & 1.5 & 1.5 & 6.0 & 0.0 & 1.4 & 1.6 & 0.0 & 1.3 & 5.1 & 2.1 \\
\hline $41-50 \%$ & 1.4 & 1.5 & 0.0 & 0.0 & 0.0 & 2.8 & 1.6 & 1.7 & 1.3 & 3.4 & 1.4 \\
\hline More than $50 \%$ & 8.3 & 4.6 & 3.0 & 4.5 & 5.1 & 5.6 & 6.2 & 13.5 & 16.2 & 5.1 & 7.3 \\
\hline Can’t say & 2.8 & 0.0 & 0.0 & 0.0 & 1.7 & 0.0 & 0.0 & 0.0 & 4.1 & 5.1 & 1.4 \\
\hline
\end{tabular}

up to $10 \%$. PR is one of the few industries where new market players did emerge. One of the segment's specific features is the inefficiency of cost-cutting strategies. The experts did not see any grounds to speak about a crisis in this industry, because major players were quite optimistic while the fears of small and weak participants were inevitable and not connected with the recession.

In IT consulting services, the share of companies whose revenues significantly fell during the first six months of 2015 was $40 \%$, or slightly more than the sector's average (Table 4). The share of companies whose revenues have slightly increased was below average, and of those who achieved more than $10 \%$ growth was the lowest among all industries of the sector - $67 \%$ below the average value. Possibly this was due to the 'Olympic Games effect' noted by the experts. Almost a quarter of the companies operating in this industry have a share of unpaid bills between $11 \%$ and $20 \%$, while the average figure for the KIBS sector is $33 \%$ smaller (Table 9).

\section{Audit services}

Audit is compulsory in many industries, so a certain share of the market remains unchanged regardless of the economic situation. In particular, the voluntary audit market remains highly stable. At the same time, since 2015 companies have been gradually abandoning their previous focus on reporting to international standards. Cost-cutting in the industry is based on optimising business processes without any significant personnel cuts. Generally, the industry's main challenges are associated not so much with the overall economic recession as with the regulator's policies; therefore, the latter sets the vector for the industry's development.

The experts' assessments were confirmed by quantitative data. The share of audit and management consulting companies, which received full payment from their customers on time (53\%) is higher than the average for the KIBS sector (49.5\%) (Table 9). Typically, the industry boasts the largest share of companies who have managed to retain all their customers (44.0\%, against the $34.5 \%$ average for the sector). However, the share of companies who were unable to bring in new partners is also quite large (25.8\%, against the $19.7 \%$ average for the sector) (Tables 7 and 8 ). The number of employees (Table 5) and labour cost (Table 6) dynamics are in line with the sector's averages.

\section{Management consulting services}

The surveyed experts noted that two contradictory trends collided in 2014: the number of potential customers' enquiries significantly grew (by 50-65\%), while the rate of their conversion into actual orders

Table 8. Breakdown of the knowledge-intensive services sector companies by share of customers lost between early autumn of 2014 and late summer of 2015, by industry (\%), $n=656$

\begin{tabular}{|c|c|c|c|c|c|c|c|c|c|c|c|}
\hline \multicolumn{12}{|c|}{$\begin{array}{l}\text { Question to respondents: Please estimate the share of customers (\%) who have left the market during the last } \\
18 \text { months compared with the total number of your company's clients in the first quarter of } 2014\end{array}$} \\
\hline & Adv & Cons & Aud & IT & HR & Eng & Fin & Law & Dev & Web & All \\
\hline All our customers are still there & 22.2 & 36.9 & 44.0 & 40.3 & 37.3 & 35.2 & 39.1 & 27.1 & 24.3 & 40.7 & 34.5 \\
\hline $5-10 \%$ & 27.8 & 30.8 & 21.2 & 32.8 & 23.7 & 16.9 & 26.6 & 20.3 & 14.9 & 35.6 & 24.8 \\
\hline $11-20 \%$ & 22.2 & 16.9 & 10.6 & 7.4 & 23.7 & 14.1 & 15.6 & 23.7 & 13.5 & 10.1 & 15.7 \\
\hline $21-30 \%$ & 9.7 & 1.5 & 7.6 & 3.0 & 3.4 & 9.9 & 3.1 & 10.2 & 14.9 & 3.4 & 6.9 \\
\hline $31-40 \%$ & 6.9 & 3.1 & 12.1 & 3.0 & 3.4 & 7.0 & 3.1 & 1.7 & 5.4 & 3.4 & 5.0 \\
\hline $41-50 \%$ & 5.6 & 0.0 & 0.0 & 6.0 & 0.0 & 1.4 & 0.0 & 3.4 & 4.0 & 0.0 & 2.1 \\
\hline More than $50 \%$ & 2.8 & 4.6 & 3.0 & 4.5 & 0.0 & 5.6 & 1.6 & 11.9 & 12.2 & 0.0 & 4.7 \\
\hline Can't say & 2.8 & 6.2 & 1.5 & 3.0 & 8.5 & 9.9 & 10.9 & 1.7 & 10.8 & 6.8 & 6.3 \\
\hline
\end{tabular}


Table 9. Breakdown of the knowledge-intensive services sector companies by share of bills not paid on time during the first six months of 2015, by industry (\%), $n=656$

\begin{tabular}{|l|r|r|r|r|r|r|r|r|r|r|r|}
\hline \multicolumn{8}{|c|}{ Question to respondents: Please estimate the share of amounts due to your company but not paid on time (\%) } \\
in the total contract value for the first six months of 2015 \\
\hline
\end{tabular}

decreased. The average order value (the average bill) also fell, while the overall market volume decreased by $10 \%$. The same trends continued in 2015. New players do emerge, but as one-off niche occurrences. The main problem appears to be that management of most companies see management consulting as something unnecessary - the first thing to go when the economic situation deteriorates.

\section{Knowledge management services}

'Old' and 'new' player concepts are not applicable at this market, which is just emerging and remains quite small. The overall number of relevant companies is very low, the market can hardly be seen as independent and is usually included in the auditing, consulting, or HR segments. If significant growth was noted here in 2014, in 2015 the market contracted, with turnover falling to a fraction of its previous size.

The industry's key problem is that relevant budgets in most companies are controlled by HR departments and are seen as costs, not investments, i.e., the first to be cut. The experts believe, however, that players in this market can overcome the recession quite quickly if they adopt 'smart entrepreneurship' logic and create added value through efficient cooperation, inclusion, and monetisation.

\section{IT services}

The experts confirmed that the currency in which the IT services market is measured is crucially important. The Russian market is a part of the global one, the largest international companies are present here, and leading Russian players view themselves in the global context. Accordingly, the market's volume should be estimated using the relevant global currency, US dollars, not roubles. Though a certain amount of growth was noted in the industry in 2014 (the share of companies whose rouble revenues' growth rate was higher than the sector's average, see Table 4), estimates in US dollars vary from 3-4\% growth to $10-12 \%$ decline. Estimates of the industry's development in 2015 also very much depend on the exchange rate fluctuations; this is where the main effect of the recession was felt.

At the end of 2014, some of the customers stepped up their procurement activities, fearing the rouble would fall even further, new sanctions would be imposed banning supplies/imports of equipment, etc. A certain positive impulse was created by the import substitution initiatives, and by players' migration from western venues to Russian ones due to adoption of the legislation on personal data storage. These factors may partially explain the relatively high share of companies operating in this industry who have managed to bring in new clients in 2014 and during the first half of 2015 (Table 7). Due to the same reason, despite obvious economic problems the rouble-denominated turnover kept growing - which allowed the experts to speak not about a recession but a certain "volatility" in the industry. However, customers' budget cuts have affected the IT services industry too: growth here largely depends on the growth of GDP. Accordingly, further growth of this market cannot be expected before we see positive GDP dynamics.

\section{HR services}

Medium and small companies have been quickly disappearing in this industry in recent years, due to their absorption by larger firms, leading professionals' opting to work remotely for their former clients or as freelancers. Still, new players do emerge in the industry. According to the respondents, HR companies are trying to make good use of their internal potential, and the current demand for high-quality HR services is even higher than it was in 2013. This might explain why all companies covered by the Monitoring study, firms specialising in this industry had the highest shares of those who have managed to retain the level of sales ( $44.1 \%$ against $31.2 \%$ average for the sector, see Table 4$)$, the number of employees $(62.7 \%$ and 
$52.4 \%$, respectively, Table 5), and the average wage $(69.5 \%$ and $56.1 \%$, respectively, Table 6$)$. However, the market fell in 2015, by between 20\% (an optimistic expert assessment) and 40-50\% (according to the pessimists).

The unfavourable developments in the economy prompted customers to optimise their costs, first of all labour costs. But as one of the experts noted, "the cuts were about money, ... not about jobs". The way HR services are provided has also changed, up to a point. Company owners demand unorthodox solutions which their in-house HR departments (often staffed by insufficiently skilled workers) are frequently unable to provide. Therefore, HR companies experienced a relatively smaller loss of revenues, less significant layoffs (Tables 4 and 5) and wage cuts (Table 6). The experts noted a shortage of relevant competences on the market, and HR companies' inability to quickly restructure, offer new services, and prove how essential they are.

\section{Engineering services}

The events of recent years only promoted demand for services like engineering design of production facilities, upgrading existing installations, etc. Still, the experts noted a very low level of clients' enquiries turning into actual orders in this market - whose current volume is estimated to be much smaller than its potential. The current recession, economic and political challenges do exacerbate the situation, but they did not create it. The main risks are associated with the evolution of the consumer profile and preferences. The market for engineering design of production facilities is one of the few whose prospects look quite optimistic. Growth rate here depends not so much on the overall economic situation as on more fundamental factors, such as refocusing government support towards sectors with higher potential. The experts also pointed out the insufficiently clear definition of engineering as a concept, and the resulting legal uncertainty.

A certain dependency on the order portfolio remains on the investment and construction engineering services market. The launch or completion of major projects in this field can significantly affect employment - which explains the highest share of engineering companies who in the first six months of 2015 have conducted major layoffs (12.7\% against the 6.3\% average for the KIBS sector) and significantly cut wages ( $8.5 \%$ against $4.5 \%$, respectively) (Tables 5 and 6$)$. Another specific feature of this industry is many companies' inability to meet clients' demands. Major players set up subsidiaries which, after the flow of orders from the parent company dries up, fail to survive on their own or diversify; their business rapidly deteriorates and in many cases, ends in bankruptcy. The investment and construction engineering services market is also highly inertial: many companies engaged in the Sochi Olympics projects still exist de jure, though do not actually function de facto - which was confirmed by the Monitoring study. So, in 2014 the share of this segment's companies who have reported more than a 10\% reduction in revenue was almost two times higher than the average for the sector (32.4\% against $17.6 \%$, respectively). During the first six months of 2015, this gap narrowed, but the share of companies whose turnover has dropped remained one of the highest (Table 4).

Due to the inertia, short-term forecasts for the investment and construction engineering services industry do not look favourable. The reduced volatility of the rouble, and the launch of new public investment programmes could contribute to this market's recovery. The improved overall economic situation may also lead to the stabilisation of customers' strategies and long-term plans, which would allow the market players to balance their portfolios and increase the stability of their businesses. The recession seems to have affected these companies' customers more than others: during the first six months of 2015 the share of engineering companies whose bills were fully paid on time was the lowest in the KIBS sector: just $36.6 \%$, against the $49.5 \%$ average (Table 9). The engineering services segment also has the highest share of companies (36.6\%) with no new partners added to their client base (Table 7).

\section{Financial intermediation services}

The problems players in this segment face are similar to the ones experienced in certain other industries. Many service types are not clearly defined in legislation, with no regulations on licensing, certification, or prudential supervision. The number of credit brokers has noticeably decreased against this background, though due to low entrance barriers the experts did not see this trend as a sign of crisis for the industry. Furthermore, the credit brokerage market displays quite unusual overall dynamics: during quiet periods demand for such services drops, in line with increasing general literacy of entrepreneurs and individual consumers alike, while during a recession the number of customers grows because the potential for finding required financial resources on their own diminishes. This market was expected to contract to a fraction of its size in 2015 compared with 2014, due to reduced overall credit availability. However, the recession was not too deep compared with other industries. The share of financial brokers whose turnover fell more than $10 \%$ in the total number of the segment's companies is almost the lowest in the KIBS sector. Note that if in 2014 it was 10.9\% (against the 17.6\% average for the sector), in the first six months of 2015 the gap became much wider. Amid the economic recession, the share of financial brokers whose turnover was declining reached $21.9 \%$, with the average value for the sector being $37.7 \%$ (Table 4 ). 
The growth rate of the insurance brokerage market in 2015, in rouble terms, slowed down from $20 \%$ (the 2013-2014 level) to 7-8\%; in US dollar terms it fell even more. The decline began in 2014 (2\%) and continued in 2015, reaching almost $40 \%$. The experts noted a stronger inertia on the leasing services market: the reduced number of companies set up in 2014-2015 will become apparent only a year or two later, by 2017. Also, since the growth of the leasing services market directly depends on the overall level of investments in the economy, in rouble terms the market may recover as early as next year, but in US dollar terms its volume would remain 50\%-67\% times lower.

\section{Legal services}

One of the consequences of the recession in this industry was an outflow of its personnel into large companies' legal departments. The share of companies who have laid off 5-20\% of their staff in the total number of firms is much higher than in any other industry (at 30.5\%), and twice as high as the average for the KIBS sector (Table 5). Many customers, first of all corporate ones, prefer to make do with their own legal departments, and contract external firms only to deal with particularly complex problems. Of the ten industries covered by the Monitoring study, only in two was the share of companies who have managed to retain all their customers between 2014 and the summer of 2015, lower than the legal services segment (Table 8). The industry has one of the highest shares of companies who have lost more than half of their client base during the same period (11.9\%, against $4.7 \%$ average for the sector). The companies are also changing their strategies, which is not very obvious due to the closed nature of their activities. Still, some changes can be detected. For example, law firms started to engage external experts more frequently, to consult on their development strategies (such as marketing), or even offer products based on a blend of IT and legal services.

A distinctive feature of the legal services market is the large number of new entrants combined with the fragmentation of companies, including large ones. This probably explains the relatively significant client base fluctuations: the segment features one of the highest values for the share of companies who have lost more than $50 \%$ of their clients, and the share of new customers of such firms comprises more than $50 \%$ of the client base (Table 7). Any person with relevant education can become a provider of legal services, so the oversupply of such professionals (pointed out by the experts) does not help the industry's development because it creates an excess supply of low-quality services. This is one of the biggest challenges for the sector, meeting which requires further consolidation of the legal services industry as a whole.

\section{Development and real estate services}

Most of the developer companies still remained on the market at the beginning of 2015, having cut their costs and laid off personnel, but the experts predict mass bankruptcies in the industry in the very near future. In all three groups of companies which have resorted to cutting wages (by less than 5\%, 5-20\%, and more than 20\%), and in two out of three groups of firms which had to lay off staff (by less than 5\%, and 5-20\%), the share of companies in this segment is higher than the sector's average (Tables 5 and 6). Excess demand was noted at the end of 2014, probably caused by the volatility of the rouble, but starting in the second quarter of 2015 a serious recession became evident in the industry. The turnover in the home real estate segment fell by $30-40 \%$, and in the commercial real estate segment - to a fraction of its previous volume. This was probably the reason the industry's performance in 2014 was on a par with the sector's average or even higher regarding the share of companies which managed to increase their roubledenominated revenues by about $10 \%$ (Table 4). In the first six months of 2015, the situation became radically different: as in advertising, the development and real estate services industry showed the highest share of companies whose turnover fell by more than $10 \%(48.6 \%)$.

In terms of customers' attitude, the industry in question is among the most secure ones: $73 \%$ of companies (much more than in any other KIBS industry) reported that during the first six months of 2015 they received full payment for services provided on time (Table 9). However, the experts noted that customers were unwilling to pay the prices charged by sellers. Accordingly, realtors have to convince the latter that prices are not going to return to the previous level in the near future, so they have to bear certain losses. Against this background, the client base remains highly volatile: the segment features particularly high shares of companies who have lost a significant portions of former clients, and of those who have managed to attract new ones (Tables 7 and 8).

According to the experts, this market will not start to recover before the rouble-to-dollar exchange rate fluctuations return to within $10 \%$ a year. The current recession in the industry may be considered a continuation of the 2009 crisis, and the experts link hopes for full recovery with introducing a legal requirement to conduct all real estate operations through realtor agencies or licensed realtors.

\section{Design services}

Providers of design services do not have to be specially registered, so this market is hard to assess. Thousands of new firms come and go every year, plus a multitude of small players and freelancers. There is no clear competition in the industry since each designer in effect sells their own unique vision. Not 
just some of the second echelon companies had to leave the market, but also some quite reputable performers - this was due to the fact that demand is shrinking while the economic and political situation frequently forces potential customers to abandon their plans to invest in an office in Russia.

A downside of excessive supply is low product quality (similar to the aforementioned situation in the legal services market), which creates demand for services to repair faulty work. As in the advertising services market, designers became more willing to take on small-scale orders. Due to a significant reduction of the overall number of orders (by 30\%), and of their average value (by 25\%), the market contracted in 2015 by about $50 \%$. According to other estimates, the decline was not that big but still quite significant, between $25-40 \%$, and very much uneven: some companies' turnover has dropped by as much as $80 \%$, while others have retained their revenues - but had to perform much more work to achieve that. The experts link recovery prospects with the stabilisation of political and economic situation. The significant positive impact the Sochi Olympics and the Kazan World Student Games have made on the market may be soon repeated due to Russia hosting the 2018 FIFA World Cup.

\section{Web and digital services}

This segment appears to be the most successful and dynamic in the sector. In 2014, a third of the players reported a more than $10 \%$ growth of rouble-denominated revenues (against the $20.7 \%$ average for the sector). The 'mirror' situation also looks similar: the share of web and digital services companies whose revenues have dropped by more than $10 \%$ in 2014 is 50\%-83\% smaller than in other segments of the sector, and $67 \%$ smaller than the KIBS sector average (Table 4). No changes were noted during the first six months of 2015 either: the share of companies whose revenues have dropped by more than 10\% was 18.6\% (against the $37.7 \%$ average for the sector), while the share of companies whose revenues grew by more than $10 \%$ reached $25.4 \%$ - much more than the sector's average of 9.9\%. Accordingly, layoffs (Table 5) and wage cuts (Table 6) affected the industry less significantly than other segments of the KIBS sector.

Professionals suggested a long time ago that digital services should be viewed as a separate category at the junction of the internet and other KIBS sector segments (such as HR, marketing, advertising services and so on). In this case, the internet and social media are seen as a specific area of companies' operations. In most industries that was where the experts noted emergence of new service types on the market. At the same time, the internet and social media remain an interactive environment inside which various specific areas emerge and grow, such as the internet of things (internet-based management and control systems as a type of IT services), internet advertising providing direct feedback from clients, or innovative legal services such as domain name protection.

\section{Conclusion}

Our study examined the effect of the late 2014 - early 2015 recession over the Russian knowledgeintensive business services sector. We have analysed indicators reflecting the performance of companies who provide such services. We established that during the first six months of 2015 the share of companies whose rouble-denominated turnover (revenue) fell more than 10\% has doubled, reaching 37.7\%. Given the volatile exchange rate of the rouble during the period in question, the experts suggested that the performance of certain industries (for example, IT services) also be assessed using foreign currency. The employment and wage dynamics were studied too, as major (amounting to up to 50\% of the total) cost items for the sector's companies.

Particular attention was paid to demand for knowledge-intensive services. We established that less than half of the companies receive payment for services provided in full and on time. Changes in the client base were analysed, including the emergence of new clients and loss of old ones. Following the logic of modern empirical studies, we analysed each of the sector's industries individually. The results confirmed the hypothesis about the high diversity in the KIBS sector. The decline in such segments as engineering or real estate and development services looks particularly severe even against the background of the overall contraction of the sector. The situation in the digital services segment appears to be more optimistic, the decline here was significantly less serious than the average values for the sector.

The study demonstrated that the KIBS sector was negatively impacted by the recession. The less than optimal development during the period following the 2008 crisis (see [Berezin, Doroshenko, 2015]) aggravated the situation even further. This trend is evident in all industries, despite significant differences between them. The sector's companies were rather optimistic about their own future though, which the experts attributed to the fact that in effect they have reached the bottom. In other words, in the current situation, even a slight improvement may be seen as noticeable growth. However, currently this sector, with its potentially high productivity, added value, and innovation potential, remains a hostage of an economic situation that does not allow it to start growing. We have to expect that the knowledgeintensive services sector will continue to contract.

This paper is based on the study "Monitoring of Knowledge-Intensive Business Services in Russia" conducted in the framework of the Basic Research Programme at the National Research University Higher School of Economics (HSE) and supported within the framework of a subsidy by the Russian Academic Excellence Project "5-100". 


\section{References}

Asikainen A-L. (2015) Innovation modes and strategies in knowledge intensive business services. Service Business, vol. 9, no 77, pp. 77-95.

Aslesen H.W., Isaksen A. (2010) Knowledge-Intensive Business Services as knowledge mediators in different regional contexts: The case of Norway. Knowledge-intensive Business Services: Geography and Innovation, Burlington, VT: Ashgate Publishing, pp. 99-122.

Berezin I. (2016) Ekspertnye otsenki ob"ema i dinamiki rynkov intellektual'nykh uslug v Rossii 2005-2015 [Expert assessment of the amount and dynamics of intellectual services markets in Russia 2005-2015]. Marketing v Rossii 2016. Spravochnik Gil'dii Marketologov [Marketing in Russia 2016. Marketers Guild Guide] (ed. I. Berezin), Moscow: Marketers Guild, pp. 33-70 (in Russian).

Berezin I., Doroshenko M. (2015) Kolichestvennye i kachestvennye izmeneniya na rynke intellektual'nykh uslug v Rossii 2005-2013 [Quantitative and qualitative changes on the market on intellectual services in Russia in 20052013]. Marketing v Rossii 2015 [Marketing in Russia 2015] (ed. I.S. Berezin). Moscow: Marketers Guild, pp. 85-128.

Bettiol M., Di Maria E., Grandinetti R. (2011) Market extension and knowledge management strategies of knowledgeintensive business services. Knowledge Management Research \& Practice, vol. 9, pp. 305-314.

Camacho J.A., Rodriguez M. (2008) Patterns of innovation in the service sector: Some insights from the Spanish innovation survey. Economics of Innovation and New Technology, vol. 17, no 5, pp. 459-471.

CBR (2016a) Dinamika ofitsial'nogo kursa zadannoi valyity [Dynamics of official course of specific currency]. Available at: http://www.cbr.ru/currency_base/dynamics.aspx, assessed 02.05.2016.

CBR (2016b) Obzor bankovskogo sektora Rossiiskoi Federatsii (internet-versiya) [Review of the Russian banking sector (online-version)]. Available at: http://www.cbr.ru/analytics/bank_system/obs_1601.pdf, assessed 02.05.2016.

Charmaz K. (2006) Constructing grounded theory: A practical guide through qualitative analysis, Thousand Oaks, CA: Sage.

Consoli D., Elche-Hortelano D. (2010) Variety in the knowledge base of Knowledge Intensive Business Services. Research Policy, vol. 39, pp. 1303-1310.

Corrocher N., Cusmano L., Morrison A. (2009) Modes of innovation in knowledge-intensive business services evidence from Lombardy. Journal of Evolutionary Economics, vol. 19, no 2, pp. 173-196.

Doloreux D., Freel M., Shearmur R. (2010) Introduction. Knowledge-intensive Business Services: Geography and Innovation, Burlington, VT: Ashgate Publishing, pp. 1-18.

Doloreux D., Shearmur R. (2010) Exploring and comparing innovation patterns across different knowledge intensive business services. Economics of Innovation and New Technology, vol. 19, no 7, pp. 605-625.

Doloreux D., Shearmur R. (2013) Innovation Strategies: Are Knowledge-Intensive Business Services Just Another Source of Information? Industry and Innovation, vol. 20, no 8, pp. 719-738.

Doroshenko M., Miles I., Vinogradov D. (2013) Knowledge intensive business services as generators of innovations (HSE WP BRP «Science, Technology and Innovation» no 12), Moscow: NRU Higher School of Economics.

Doroshenko M., Miles I., Vinogradov D. (2014) Knowledge Intensive Business Services: The Russian Experience. Foresight and STI Governance, vol. 8, no 4, pp. 24-39.

Freel M. (2010) Knowledge-Intensive Business Services users and uses: Exploring the propensity to innovation-related cooperation with Knowledge-Intensive Business Services. Knowledge-intensive Business Services, Burlington, VT: Ashgate Publishing, pp. 75-98.

Green J., Thorogood N. (2004) Qualitative methods for health research (1st ed.), London: SAGE Publications Ltd.

Griffin A., Hauser J. R. (1993) The voice of the customer. Marketing Science, vol. 12, no 1, pp. 1-27.

Marasco A., Masiello B., Izzo F. (2013) Client involvement and innovation in Creative-Intensive Business Services: A framework for exploring co-innovation in advertising agency-client relationships. Economies et Sociétés, vol. 47, no 3-4, pp. 445-478.

Miles I. (1993) Bringing computer power to the consumer market. Technology Analysis \& Strategic Management, vol. 5, no 2, pp. 151-172.

Miles I. (2011) Servisnye innovatsii v XXI veke [Service Innovation in the Twenty First Century]. Foresight-Russia, vol. 5, no 2, pp. 4-15 (in Russian).

Muller E., Doloreux D. (2009) What we should know about knowledge-intensive business services. Technology in Society, vol. 31, pp. 64-72.

Muller E., Zenker A. (2001) Business services as actors of knowledge transformation: The role of KIBS in regional and national innovation systems. Research Policy, vol. 30, no 9, pp. 1501-1516.

Quandl (2016a) Services share of GDP by country (from World Bank cross country data). Available at: https://www. quandl.com/collections/economics/services-share-of-gdp-by-country, accessed 02.05.2016.

Quandl (2016b) Services share of employment by country (from World Bank cross country data). Available at: https:// www.quandl.com/collections/economics/services-share-of-employment-by-country, accessed 02.05.2016.

Rosstat (2016a) Natsional'nye scheta [National accounts]. Available at: http://www.gks.ru/wps/wcm/connect/rosstat_ main/rosstat/ru/statistics/accounts/\#, assessed 02.05.2016.

Rosstat (2016b) Tseny [Prices]. Available at: http://www.gks.ru/wps/wcm/connect/rosstat_main/rosstat/ru/statistics/ tariffs/\#, assessed 02.05.2016.

Rozhdestvenskaya E. (2012) Biograficheskii metod v sotsiologii [Biographical method in sociology], Moscow: NRU Higher School of Economics.

Santos-Vijande M.L., González-Mieres C., López-Sánchez J.A. (2013) An assessment of innovativeness in KIBS: Implications on KIBS' co-creation culture, innovation capability, and performance. Journal of Business \& Industrial Marketing, vol. 28, pp. 86-102.

Thomson S.B. (2011) Sample Size and Grounded. Theory. JOAAG, vol. 5, no 1, pp. 45-52.

Zieba M. (2013) Knowledge-Intensive Business Services and their role in the knowledge-based economy (GUT Working Paper Series A (Economics, Management, Statistics) no 7/2013 (7)), Gdansk: Gdansk University of Technology. 